\title{
Mechanism of Inhibition of Porcine Elastase by Human
}

\section{Alpha-1-Antitrypsin}

\author{
Harold L. James and Allen B. Cohen, Department of Medicine, Temple University, \\ Health Sciences Center, Philadelphia, Pennsylvania, 19140
}

\begin{abstract}
A B S T RACT The interaction of the human plasma protein, alpha-1-antitrypsin, with poreine pancreatic elastase was studied by isolating and characterizing their reaction products. Native alpha-1-antitrypsin has a mass ratio (Mr) of 54,000, an amino-terminal glx, and a carboxy-terminal lys residue. The elastase used has an $\mathrm{Mr}$ of 26,400 and an amino-terminal val residue. When the two proteins are combined at inhibitor excess, two major products result. One of the products is a complex of the enzyme and inhibitor with amino-terminal ser and val residues, which indicates that a peptide has been removed from the amino-terminal end of the inhibitor. The second product is a modified form of alpha-1-antitrypsin with an $\mathrm{Mr}$ of 51,300, an aminoterminal glx residue and a carboxy-terminal thr-leu dipeptide. It has no inhibitory activity against elastase. The components of the isolated complex can be split at high $\mathrm{pH}$ in the presence of diisopropyl fluorophosphate, which results in a catalytically inactive enzyme with the same $\mathrm{Mr}$ and amino-terminal residue as the native enzyme, and a large fragment of alpha-1antitrypsin (alpha-1-antitrypsin*). This fragment has an $\mathrm{Mr}$ of 50,100, an amino-terminal ser residue and a carboxy-terminal thr-leu dipeptide. Based on these data, the following hypothesis is proposed. Elastase can attack alpha-1-antitrypsin at either of two major sites. If it attacks first at the carboxy side of the thr-leu dipeptide, located in the carboxy-terminal portion of the inhibitor, the alpha-1-antitrypsin is cleaved into two fragments with loss of inhibitory activity and absence of complex formation. If, however, the elastase first attacks an $x$-ser bond near the amino-terminal end of the inhibitor, the elastase then reacts with alpha-1antitrypsin at the same leu moiety to form a stable complex with complete inhibition of the enzyme.
\end{abstract}

Received for publication 3 March 1978 and in revised form 21 August 1978.

\section{INTRODUCTION}

Individuals who have a genetically determined low concentration of alpha-1-antitrypsin in their blood usually develop pulmonary emphysema at an early age (1). Because alpha-1-antitrypsin is known to be a protease inhibitor (2), emphysema in such patients might logically be attributed to the unrestrained action of an enzyme or several enzymes on pulmonary tissues (3). Alpha-1-antitrypsin is a glycoprotein in plasma which inhibits many proteolytic enzymes. The pathologic and physiologic derangements characteristic of pulmonary emphysema can be induced in small animals by introducing proteolytic enzymes of the elastase class into their lungs. We have therefore studied the mechanism by which alpha-1-antitrypsin inhibits elastases.

Elastases are enzymes which catalyze the hydrolysis of certain peptide bonds in native elastin. These enzymes usually cleave proteins or amide or ester substrates at amino acids with small aliphatic side-chains (4). Trypsin (5) has been shown to attack a lys-x peptide bond in alpha-1-antitrypsin; however, it then forms a stable tetrahedral or acyl complex with the inhibitor which does not hydrolyze as do similar bonds in other proteins. If elastases are inhibited by a similar mechanism, then they probably attack alpha-1-antitrypsin at a specific residue at the active site for elastase, and become tightly bound to the inhibitor. It is quite likely that all elastases inhibited by alpha-1-antitrypsin are bound to the inhibitor at the same site, which makes it reasonable to investigate the elastase inhibitory site with the most available and best characterized elastase, that derived from porcine pancreas (6).

It would be premature to draw conclusions at this time as to which elastase, if any, causes damage to emphysematous lungs. Several enzymes with possible access to the lung include elastases from neutrophils $(7,8)$, platelets $(9)$, and alveolar macrophages $(10)$.

In previous work, we (11) and others (12) have re- 
ported that a number of complexes of different molecular weight form between alpha-1-antitrypsin and pancreatic elastase which can be demonstrated on polyacrylamide disc-gel electropherograms in sodium dodecyl sulfate (SDS-PAG). ${ }^{1}$ In the experiments reported herein, we describe conditions under which a complex was sufficiently stable to be isolated. The enzyme and inhibitor components were then separated from each other and characterized. A preliminary report on the essential aspects of this work has been made (13).

\section{METHODS}

Isolation of alpha-1-antitrypsin. We have combined the most effective steps in each of several published methods (14-17) to achieve an optimal method of isolation. All purification steps were carried out at $5^{\circ} \mathrm{C}$ except for the thiol Sepharose 4B mixed disulfide interchange column (Pharmacia Fine Chemicals, Div. of Phamacia Inc., Piscataway, N. J.), which was operated at room temperature. All samples of alpha-1antitrypsin, elastase, and fractions obtained at selected purification steps were stored at $-20^{\circ} \mathrm{C}$. Blood from volunteer donors known to possess alpha-1-antitrypsin of phenotype MM, collected in acid-citrate-dextrose anticoagulant, was used on the same day of collection to obtain platelet-poor plasma by differential centrifugation. Plasma not immediately used was quick-frozen and stored at $-20^{\circ} \mathrm{C}$ until needed. Alpha-1-antitrypsin was isolated from plasma thus obtained by the procedure recently established in this laboratory (18) that involves salt precipitation, removal of albumin with insolubilized Cibacron Blue dye (Ciba-Geigy Corp., Pigments Dept., Ardsley, N. Y.), further fractionation with two different anion-exchange columns, and finally a disulfide interchange column. The purified alpha-1-antitrypsin was dialyzed extensively in Tris- $\mathrm{HCl}, 0.05 \mathrm{M}, \mathrm{pH} 7.5$, containing sodium chloride, $0.1 \mathrm{M}$, sodium azide, $3 \mathrm{mM}$, and 2-mercaptoethanol, $1 \mathrm{mM}$.

Properties of purified alpha-1-antitrypsin. The purified alpha-1-antitrypsin in these studies inhibited an equimolar amount of active-site titrated trypsin by the $\mathrm{pH}$ Stat assay described below and had a single amino-terminal glx and a carboxy-terminal lys. It exhibited a single band on polyacrylamide gel electrophoresis with or without SDS, and had a phenotypic pattern on isoelectric focusing (19) identical to that of the normal phenotype MM. It formed a single immunoprecipitate in double immunodiffusion analysis with antisera against alpha-1-antitrypsin or whole serum, but did not react with antisera against human alpha-1-acid glycoprotein, albumin, antithrombin III, haptoglobin, alpha-l-antichymotrypsin, prealbumin, Gc-globulin, transferrin, interalpha-1-antitrypsin, or alpha-2-macroglobulin. By the single radial immunodiffusion technique, the starting plasma contained $320 \mathrm{mg}$, and the purified preparation $126 \mathrm{mg}$ of alpha1-antitrypsin, which represents a recovery of $39.4 \%$.

Trypsin inhibitory capacity. The inhibitory capacity of alpha-1-antitrypsin toward trypsin was measured with the $\mathrm{pH}$ Stat (Radiometer Co., Copenhagen, Denmark) as described by Walsh and Wilcox (20) with sodium hydroxide, $0.1 \mathrm{M}$, as

${ }^{1}$ Abbreviations used in this paper: Ac-triAla-Me, N-acetylL-alanyl-L-alanyl-L-alanine methyl ester; DFP, diisopropyl fluorophosphate; Mr, mass ratios; SDS, sodium dodecyl sulfate; SDS-PAG, polyacrylamide disc-gel electropherograms in SDS. titrant and $p$-tosyl-L-arginine methyl ester (Calbiochem, San Diego, Calif.) as substrate. The porcine trypsin (Miles Laboratories Inc., Elkhart, Ind.) used for this assay was first titrated for active sites with $p$-nitrophenyl-p-guanidino-benzoate- $\mathrm{HCl}$ (ICN Pharmaceuticals Inc., Cleveland, Ohio) by the method of Chase and Shaw (21). It was found to be $85 \%$ active with this titrant. The Mr used for alpha-1-antitrypsin and trypsin were 54,000 (11) and $24,000(22)$, respectively. The purified alpha-1-antitrypsin used in these studies was capable of completely inhibiting trypsin in this assay at a calculated inhibitor to active enzyme ratio of $2.25 \mathrm{mg}( \pm 3 \%)$ to $1 \mathrm{mg}$. This ratio corresponds to that for equimolar amounts of inhibitor and enzyme.

Purification of elastase, titration with alpha-1-antitrypsin, and active-site titration. Elastase was isolated from an acetone powder of porcine pancreas, Trypsin 1-300 (ICN Pharmaceuticals Inc.), according to the method of Shotton (6). The purified product was reacted with L-1-tosylamide-2-phenylethyl-chloromethyl ketone and $\mathrm{N}-\alpha-p$-tosyl-L-lysine-chloromethyl ketone-HCl (Sigma Chemical Co., St. Louis, Mo.), as previously described (11), to destroy contaminating chymotryptic and tryptic activities. The final elastase preparation thus treated was dialyzed in Tris- $\mathrm{HCl}, 0.1 \mathrm{M}$, containing sodium azide, $3 \mathrm{mM}, \mathrm{pH}$ 7.6. Before use in the present studies, the elastase was analyzed by active-site titration (23) with $p$-nitrophenyl-3-(N-acetyl-L-alanyl-L-alanyl)-2-methylcarbazate, kindly provided by Dr. James C. Powers, Georgia Institute of Technology, Atlanta, Ga. By this method, the elastase was found to be $94.5 \%$ active, assuming a stoichiometric reaction with the titrant, and comparing the result with the absorbancy of the enzyme preparation at $280 \mathrm{~nm}$.

The purified elastase was titrated with purified alpha-1antitrypsin in the $\mathrm{pH}$ Stat system described above, except that $0.02 \mathrm{M} \mathrm{N}$-acetyl-L-alanyl-L-alanyl-L-alanine methyl ester (Ac-triAla-Me) (Calbiochem) was used as substrate (24). The $\mathrm{Mr}$ used for elastase in calculating the degree of inhibition by alpha-1-antitrypsin was 26,400 (11).

Radioactive labeling of elastase. Purified porcine elastase was labeled with ${ }^{125}$ I by the method of McFarlane (25), except that the preparation of working iodine-monochloride solution contained $4.2 \mathrm{mg}$ of iodine as iodine-monochloride/ $\mathrm{ml}$ (10 times the original concentration). The ${ }^{125} \mathrm{I}$-elastase had a sp act of $4.4 \times 10^{7} \mathrm{cpm} / \mathrm{mg}$. Its catalytic activity was identical to that of the unlabeled enzyme.

Amino-terminal and carboxy-terminal analyses. Aminoterminal analysis (26) was carried out with the modifications described by Mosesson et al. (27). Dansyl-amino acid derivatives thus obtained were analyzed on $5-\mathrm{cm}$ square ChengChin polyamide-coated plates (Accurate Chemical \& Scientific Corp., Hicksville, N. Y.) by the method of Woods and Wang (28).

Carboxy-terminal analysis was carried out with an enzyme from yeast (29), carboxypeptidase $\mathrm{Y}$, code COY, lot 07B01, which was obtained commercially from Worthington Biochemical Corp., Freehold, N. J. The enzyme was reconstituted at a concentration of $1 \mathrm{mg}$ protein $/ \mathrm{ml}$ in distilled water and assayed spectrophotometrically (30) with N-acetyl-L-tryosine ethyl ester. By this assay, the specific activity of the enzyme was $39.4 \mu \mathrm{mol} \mathrm{N}$-acetyl-L-tryosine ethyl ester hydrolyzed/min per $\mathrm{mg}$ protein. Protein substrates to be analyzed were first dialyzed extensively in $1 \mathrm{mM} \mathrm{HCl}$ at $5^{\circ} \mathrm{C}$, then lyophilized and dissolved in sodium acetate buffer, $0.1 \mathrm{M}, \mathrm{pH}$ 5.0 , to give a protein concentration of $2.5 \mathrm{mg} / \mathrm{ml}$. Carboxypeptidase $Y$ was then added (1:100 to $1: 20$ ratio, weight/weight, enzyme:substrate) and, after various times of incubation at room temperature, the reactions were stopped by heating at 
$100^{\circ} \mathrm{C}$ for $3 \mathrm{~min}$. Appropriate enzyme and substrate controls were included. After removal of precipitated protein by centrifugation, the total volume of each sample was made $1.0 \mathrm{ml}$ with sodium citrate- $\mathrm{HCl}$ buffer, $0.2 \mathrm{M}, \mathrm{pH} 2.2$, before total amino acid analysis (31) for released residues. The analyses, which represented either 10 or $20 \mathrm{nmol}$ of protein substrate, were carried out with the Beckman model 119 automatic amino acid analyzer (Beckman Instruments, Inc., Fullerton, Calif.) (6-h program, single column). A Beckman standard (Beckman Instruments, Inc.) that contained $25 \mathrm{nmol} / \mathrm{amino}$ acid was included.

Amino-terminal sequence analysis. This procedure was kindly carried out by Dr. S. K. Chan, Department of Biochemistry, University of Kentucky, Lexington, Ky. The sequential degradation of the purified protein was carried out in a Beckman model $890 \mathrm{C}$ sequencer (Beckman Instruments, Inc.), with the $0.1 \mathrm{M}$ Quadrol program of Brauer et al. (32).

Immunologic and electrophoretic methods. Double immunodiffusion and immunoelectrophoresis were carried out by conventional methods (33). Specific antisera for human alpha-1-antitrypsin, albumin, whole serum, alpha-1-antichymotrypsin, antithrombin III, alpha-2-macroglobulin, haptoglobulin, Gc-globulin, prealbumin, inter-alpha-1-antitrypsin, alpha-1-acid glycoprotein, and transferrin were obtained commercially (Behring Diagnostics, American Hoechst Corp., Sommerville, N. J.). Rabbit antiserum for porcine pancreatic elastase was produced in this laboratory. Quantitation of alpha-1-antitrypsin by single radial immunodiffusion was carried out by the method of Mancini et al. (34). Disc-gel electrophoresis $(7.5 \%$ acrylamide) was carried out in the absence (35) and presence (36) of SDS. To determine Mr, electrophoresis in polyacrylamide gels ( $10 \%$ acrylamide) which contained SDS was carried out after the procedure of Laemmli (37) as modified by Hokin et al. (38). Isoelectric focusing in acrylamide slab gels for the purpose of examining the phenotypic pattern of alpha-1-antitrypsin in plasma or purified preparations was carried out as described by Kueppers (19). Only plasma that exhibited the staining pattern of the normal phenotype MM was used for purification of the inhibitor.

Miscellaneous. The ${ }^{125}$ I content of liquid samples and polyacrylamide gel slices was determined in a Nuclear-Chicago automatic gamma spectrometer (Nuclear-Chicago Corp., Des Plaines, Ill.). Densitometric scans of stained polyacrylamide gels were carried out for absorbance at $580 \mathrm{~nm}$ with an ISCO model 659 densitometer (Instrumentation Specialties Co., Lincoln, Neb.). Salt gradients of ion-exchange columns were determined by measurement of the conductivity of column eluates with a Radiometer model CDM 3 conductivity meter (Radiometer Co.) and comparison with standard buffer-sodium chloride solutions.

Protein concentrations were determined by measurement of absorbance at $280 \mathrm{~nm}$ with the following extinction coefficients (absorbance of a 1\% solution, 1-cm light path): alpha1-antitrypsin, 5.0 (39); elastase, 22.2 (6); trypsin, 15.0 (22). The large fragments of alpha-1-antitrypsin which resulted from interaction with elastase, i.e., inactive alpha-1-antitrypsin and alpha-1-antitrypsin*, were calculated to have extinction coefficients of 5.3 and 5.4, respectively, by comparison of their $\mathrm{Mr}$ with that of alpha-1-antitrypsin, and assuming the same content of tyrosine and tryptophan residues (11). A calculated extinction coefficient of 12.0 for the alpha-1-antitrypsinelastase complex was derived on the basis of a 1:1 molar combination of the enzyme and inhibitor, taking into account the loss of small peptides from the inhibitor.

Ion-exchange purification steps were carried out with Whatman DE-52 cellulose anion exchange resin $H$. Reeve Angel \& Co., Inc., Clifton, N. J.). Ultrafiltration with PM 10 membranes (Amicon Corp., Scientific Sys. Div., Lexington, Mass.) was used to concentrate material recovered from columns.

\section{RESULTS}

Titration of elastase with alpha-1-antitrypsin. Mixtures of the enzyme and inhibitor were analyzed for any residual activity in the $\mathrm{pH}$ Stat, with the synthetic substrate, Ac-TriAla-Me, for measuring elastase specifically. The results are shown in Fig. 1. Molar ratios of alpha-1-antitrypsin to elastase $>2.2: 1$ resulted in complete elimination of elastase activity.

Preliminary observations on complex formation. Alpha-1-antitrypsin was combined with elastase in molar ratios of $2: 1,3: 1$, and $4: 1$, respectively, at room temperature in Tris- $\mathrm{HCl}$ buffer, $0.1 \mathrm{M}, \mathrm{pH} 7.6$, which contained sodium azide, $3 \mathrm{mM}$, for periods of $1 \mathrm{~min}$, $30 \mathrm{~min}$, and $2 \mathrm{~h}$. At the end of the incubation periods, diisopropyl fluorophosphate (DFP), $0.1 \mathrm{M}$ in isopropanol, was added to a 100:1 molar excess over the original amount of elastase to inhibit any further action of the enzyme. Components of the reaction mixture were electrophoresed on SDS-PAG. The gel patterns showed incomplete complex formation after $1 \mathrm{~min}$, but a stable pattern after $30 \mathrm{~min}$. The patterns for 3:1 and 4:1 molar ratios of inhibitor to enzyme were qualitatively the same, showing complex, alpha-1-antitrypsin and a large fragment previously identified as "inactive alpha1-antitrypsin" (11), in order of increasing mobility (Fig. 2, gel A). The sample that contained the reactants in 2:1 molar ratio also showed a low, but clearly observable, amount of protein with the mobility of free elastase, as might be expected from the results described above, and illustrated in Fig. 1, on titration of elastase with alpha-1-antitrypsin.

Isolation and analysis of the alpha-1-antitrypsinelastase complex. Because both kinetic and electrophoretic analyses demonstrated that components of the interaction of alpha-1-antitrypsin and elastase are stable when combined in a molar ratio of $3: 1$, this ratio of reactants (30-min reaction time before addition of DFP)

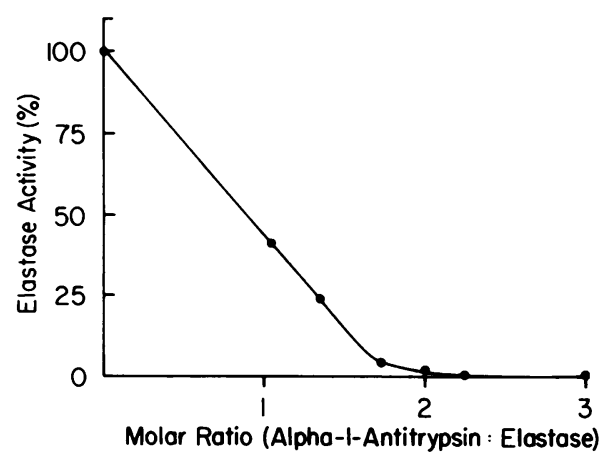

FIgure 1 Titration of elastase with alpha-1-antitrypsin. Varied amounts of purified human alpha-1-antitrypsin were preincubated with $10 \mu \mathrm{g}$ of active porcine elastase for $5 \mathrm{~min}$ at room temperature. The residual elastase activity toward Ac-triAla-Me was then measured in the $\mathrm{pH}$ Stat as described in Methods. 


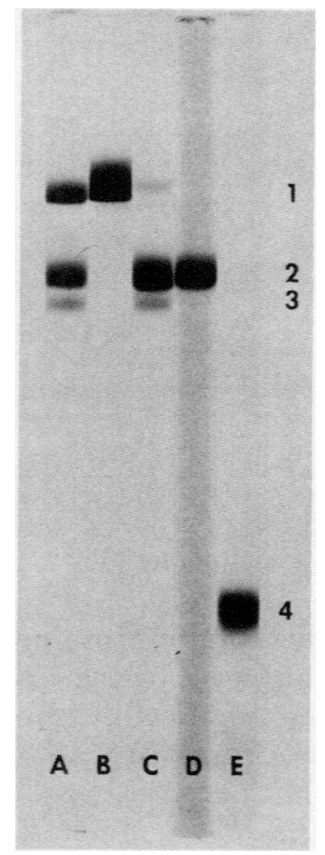

FIGURE 2 SDS-Polyacrylamide gel (7.5\% acrylamide) electropherograms of fractions obtained during purification of the alpha-1-antitrypsin-elastase complex (Fig. 3). The patterns observed represent: $A$, alpha-1-antitrypsin and elastase in 3:1 molar combination; B, peak I; C, peak II; D, native alpha-1antitrypsin; and $\mathrm{E}$, elastase. The arabic numbers to the right represent the mobility of the alpha-1-antitrypsin-elastase complex (band 1), native alpha-1-antitrypsin (band 2), inactive alpha-1-antitrypsin (band 3), and elastase (band 4). All samples contained $35 \mu \mathrm{g}$ of protein, except the elastase control which contained $20 \mu \mathrm{g}$. Anode at bottom.

was considered to provide a safe margin of inhibitory capacity for isolation of the alpha-1-antitrypsinelastase complex. Alpha-1-antitrypsin, $5.2 \mathrm{mg}$, was reacted with elastase, $0.87 \mathrm{mg}$, for $30 \mathrm{~min}$ at room temperature. Then, $0.61 \mathrm{mg}$ of DFP in $0.033 \mathrm{ml}$ of isopropanol was added to the reaction mixture, and the resultant solution was dialyzed against sodium phosphate buffer, $0.005 \mathrm{M}, \mathrm{pH} 5.5$, which contained sodium chloride, $0.05 \mathrm{M}$, and applied to a column $(0.7 \times 13$ $\mathrm{cm}$ ) of DE-52 cellulose equilibrated with the same buffer. The proteins were eluted with a linear gradient of sodium chloride from 0.05 to $0.2 \mathrm{M}$ (Fig. 3). The SDS-PAG of the initial reaction mixture and peaks I and II thus obtained are shown in Fig. 2.

The protein in peak I exhibited no catalytic activity against Ac-triAla-Me. Only peak I formed immunoprecipitin with antiserum to elastase, while both peaks I and II formed immunoprecipitates with antiserum to alpha-1-antitrypsin. The amount of complex in peak II, as illustrated by gel C of Fig. 2, was apparently not high enough to produce an observable reaction with antiserum to elastase. Whereas peak I of Fig. 3 contained only the complex, peak II contained, in addition to a

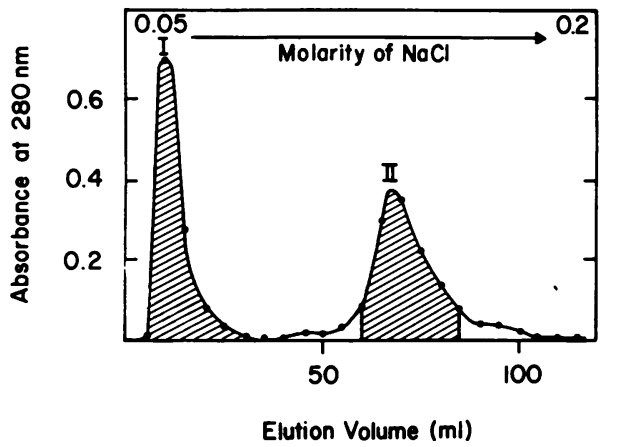

FIGURE 3 Elution profile for purification of alpha-1-antitrypsin-elastase complex on DE-52 cellulose. Fractions indicated by diagonal lines were pooled for recovery of proteins from peaks I (alpha-1-antitrypsin-elastase complex) and II (native and inactive alpha-1-antitrypsin). See text for details.

small amount of the complex, the form of alpha-1-antitrypsin previously described as inactive (11). This protein was found by SDS-PAG electrophoresis (results not shown) to be present in the descending limb of peak II, producing a trailing shoulder. It can be observed as a band, in gel C in Fig. 2, with a significantly higher mobility than that of native alpha-1-antitrypsin.

The elution profile shown by Fig. 3 is a typical one. It was found possible to obtain qualitatively the same results by fractionation of starting material prepared from $103 \mathrm{mg}$ of alpha-1-antitrypsin and $17 \mathrm{mg}$ of elastase on a $2.5 \times 36 \mathrm{~cm}$ column of DE-52. The yield of purified complex in this instance was $47 \mathrm{mg}$.

An additional means of verifying the identity and characteristics of the complex was provided through the use of ${ }^{125}$ I-labeled elastase. The same reaction mixture for formation of the complex, as described above, was prepared for SDS-PAG electrophoresis with the labeled enzyme. The stained gel was first analyzed by scaning densitometry at $580 \mathrm{~nm}$, then sectioned at $1 \mathrm{~mm}$ intervals for measurement of radioactivity. A gel that contained the purified complex was included for comparison in the densitometric analysis. The results showed that $\cong 95 \%$ of the radioactivity applied to the gel was contained in the complex band. A small peak of radioactivity that occurred at the mobility of native elastase amounted to $4.4 \%$ of the total radioactivity in the gel, although no peak of absorbance at $580 \mathrm{~nm}$ was detected at this mobility. This minor peak of radioactivity was in very good agreement with the active-site titration of the elastase employed (see Methods), whereby it was found to contain $5.5 \%$ catalytically inactive enzyme. The densitometric scan of the purified complex was identical in shape and location to the complex observed as a component of the reaction mixture, which suggests that it had not been changed during the steps employed to purify it.

The Mr of the complex was found to be about 74,100 and the amino-terminal residues by the dansyl chloride 
TABLE I

Characterization of Purified Materials Involved in Alpha-1Antitrypsin-Elastase Complex Formation

\begin{tabular}{llcr}
\hline & \multicolumn{2}{c}{ Terminal residue(s) } & \\
\cline { 2 - 3 } \multicolumn{1}{c}{ Test material } & Aminot & $\begin{array}{c}\text { Car- } \\
\text { boxy } \$\end{array}$ & Mr" \\
\hline $\begin{array}{l}\text { Alpha-1-antitrypsin } \\
\text { (native) }\end{array}$ & glx & lys & 54,000 \\
$\begin{array}{l}\text { Inactive alpha-1- } \\
\quad \text { antitrypsin }\end{array}$ & glx & thr-leu & 51,300 \\
$\begin{array}{l}\text { Elastase (native) } \\
\begin{array}{l}\text { Elastase (released from } \\
\text { complex) }\end{array}\end{array}$ & val & - & 26,400 \\
$\begin{array}{l}\text { Alpha-1-antitrypsin- } \\
\text { elastase complex }\end{array}$ & val & - & 26,400 \\
$\begin{array}{l}\text { Alpha-1-antitrypsin* } \\
\text { (released from complex) }\end{array}$ & ser, asx, val & - & 74,100 \\
\hline
\end{tabular}

† Obtained by dansyl chloride method.

\$ Obtained with carboxypeptidase $Y$.

"Determined by SDS-PAG electrophoresis.

method were ser, asx, and val (Table I). Because val is the amino-terminal residue of elastase and glx is the amino-terminal residue of alpha-1-antitrypsin, at least one (and possibly two) small peptide had apparently been cleaved from the amino-terminal end of the inhibitor during complex formation. Subsequent analysis of the amino-terminal sequence of the alpha-1-antitrypsin component (alpha-1-antitrypsin*) of the complex indicated that the ser was apparently in much higher concentration than the asx (vide infra). Thus, because the complex is a single component by SDSPAG electrophoretic analysis (Fig. 2), the major aminoterminal cleavage identifiable in alpha-1-antitrypsin on complete interaction with elastase is at an $x$-ser peptide linkage.

Isolation and characterization of inactive alpha-1antitrypsin. The last one-half of the descending limb of peak II in Fig. 3 contained inactive alpha-1-antitrypsin. However, to obtain this modified form (11) of the inhibitor in the purified state and in more adequate quantity, alternative methods were used. Thus, a column of thiol Sepharose 4B $(2 \times 20 \mathrm{~cm})$ to which 50 $\mathrm{mg}$ of alpha-1-antitrypsin has been bound (18) was reacted with $8.3 \mathrm{mg}$ of elastase (3:1 molar ratio of bound inhibitor to enzyme) for $1 \mathrm{~h}$, followed by addition and thorough mixing (by end-over-end rotation of the column) of $0.3 \mathrm{ml}(5.53 \mathrm{mg}$ ) of DFP in isopropanol. After washing out unbound protein, elution with buffer that contained $5 \mathrm{mM}$ L-cysteine- $\mathrm{HCl}$ was carried out to recover bound protein (complex, residual native alpha-1antitrypsin, and inactive alpha-1-antitrypsin). The latter mixture was then fractionated on a DE-52 column (2.6 $\times 18.5 \mathrm{~cm})$ in the same manner as illustrated by Fig. 3 . The peaks obtained (Fig. 4) were the complex (peak

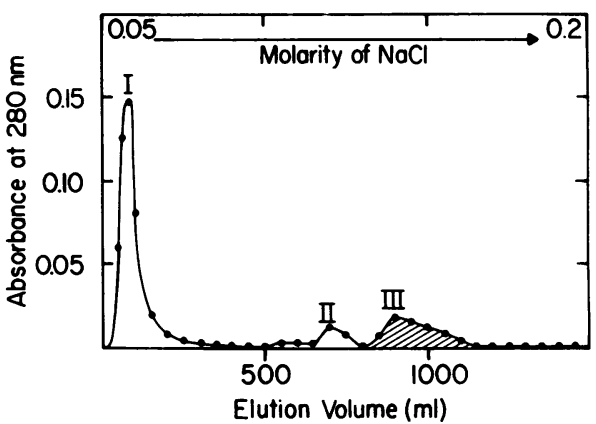

FIGURE 4 Elution profile for purification of "inactive alpha1-antitrypsin" on DE-52 cellulose. The inactive form of alpha1-antitrypsin was recovered, as indicated by diagonal lines, in peak III. See text for details.

I), residual alpha-1-antitrypsin (peak II), and "inactive alpha-1-antitrypsin" (peak III), the latter occurring in the elution profile at the same position as the trailing shoulder of peak II (Fig. 3). Approximately 5 mg of highly purified inactive alpha-1-antitrypsin (Fig. 5) was obtained. The only amino-terminal residue detected for material in peak III was glx (Table I), the same residue as the amino-terminus of native alpha-1antitrypsin $(14,15)$. As observed previously by us (11) and by others (12), the inactive inhibitor was incapable of inhibiting trypsin or elastase. The $\mathrm{Mr}$ of the purified inactive inhibitor was found to be 51,300 (Table I).

Splitting of the complex and recovery of the alpha1-antitrypsin component (alpha-1-antitrypsin*) of the complex. A preliminary study was made with the purified complex to further investigate the conditions necessary to bring about its complete cleavage within a minimal time period. The complex in Tris- $\mathrm{HCl}$ buffer, $0.1 \mathrm{M}$, pH 7.6, containing sodium azide, $3 \mathrm{mM}$, was cleaved into its enzyme and inhibitor components (11) by adjusting the $\mathrm{pH}$ to $10,11,12$, or 13 with appropriate amounts of $10 \mathrm{M}$ sodium hydroxide (final sodium hydroxide concentration of $\cong 0.08,0.10,0.13$, and $0.20 \mathrm{M}$, respectively) and incubation for $2 \mathrm{~h}$ at room temperature. 0.1 M DFP in isopropanol, was added in a 100:1 molar excess over the amount of enzyme before the $\mathrm{pH}$ was raised, and again after the 2 -h incubation. The $\mathrm{pH}$ was then returned to 7.6 with concentrated hydrochloric acid. The extent of cleavage of the purified complex, and the nature of the cleavage products thus formed was examined on SDS-PAG (e.g., Fig. 6, gel B). The complex which was cleaved at $\mathrm{pH} 12$ showed two bands, one corresponding to a protein with an $\mathrm{Mr}$ of about 50,100 (alpha-1-antitrypsin*), and the other band to an elastase control. At $\mathrm{pH}$ values of 10 and 11 , cleavage was incomplete, while at $\mathrm{pH} 13$ an additional band between alpha-1-antitrypsin* and elastase was seen on the gels. Therefore, the cleavage of the complex was carried out at $\mathrm{pH} 12$ for the isolation of alpha1-antitrypsin*. 


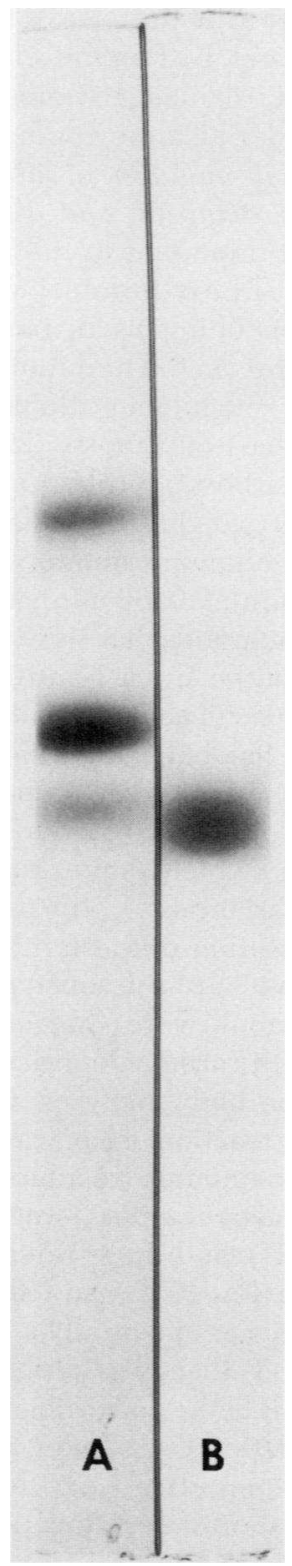

FIGURE 5 SDS-Polyacrylamide gel $(7.5 \%$ acrylamide) electropherograms of the unfractionated complex reaction mixture (gel A), and peak III of Fig. 4, purified inactive alpha1-antitrypsin (gel B). Anode at bottom.

A solution of $13.2 \mathrm{mg}$ of isolated complex in Tris$\mathrm{HCl}$ buffer, $0.1 \mathrm{M}, \mathrm{pH} 7.6$, containing sodium azide, $3 \mathrm{mM}$, was raised to $\mathrm{pH} 12$ with $10 \mathrm{M}$ sodium hydroxide (final sodium hydroxide concentration of $0.13 \mathrm{M})$. The reaction mixture was incubated at room temperature for $2 \mathrm{~h}$ in the presence of a 100 -fold molar excess of DFP over enzyme. The $\mathrm{pH}$ was returned to 7.6 with $\mathrm{HCl}$, and the solution was dialyzed extensively against sodium phosphate buffer, $0.005 \mathrm{M}, \mathrm{pH} 6.5$, containing sodium chloride, $0.025 \mathrm{M}$, and DFP, $0.001 \mathrm{M}$. The dialyzed sample was applied to a chromatographic

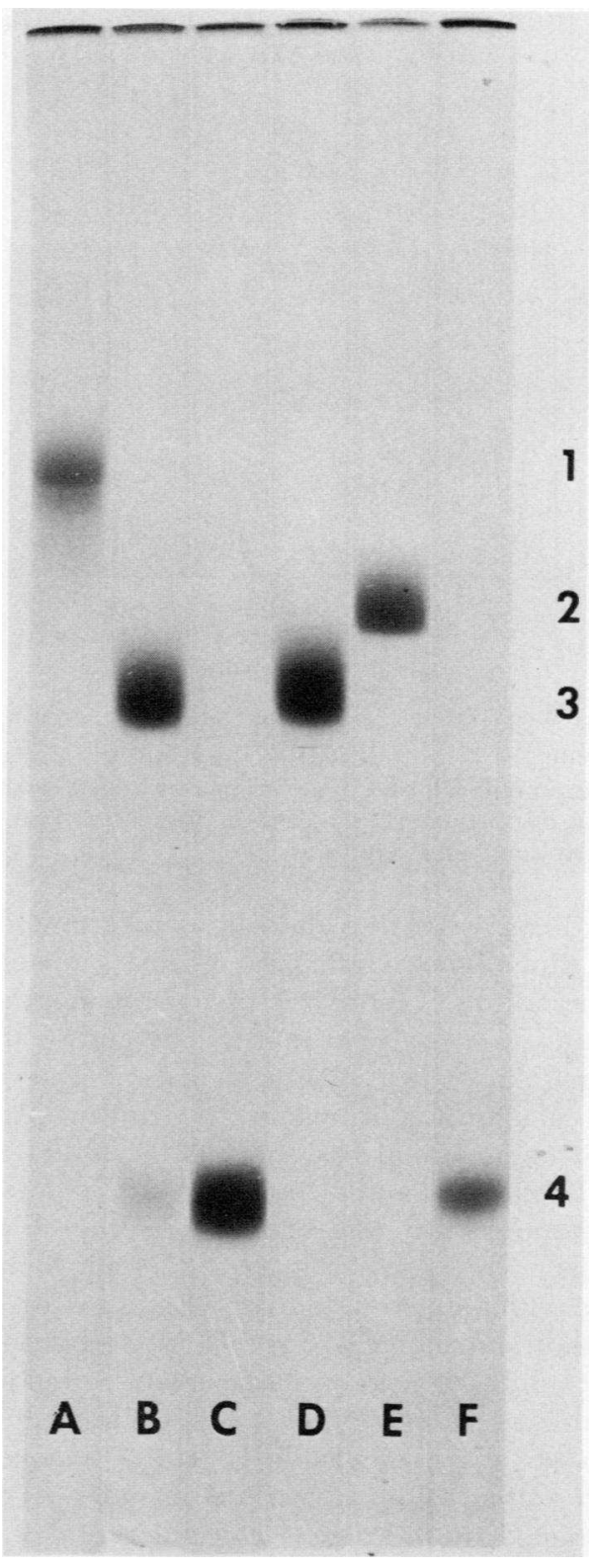

Figure 6 SDS-Polyacrylamide gel (7.5\% acrylamide) electropherograms of fractions obtained during purification of alpha-1-antitrypsin*. A, Peak I of Fig. 3 (purified complex); B, complex after being split at pH 12 (starting material for chromatogram shown in Fig. 7); C, Peak I (elastase) of Fig. 7; D, Peak II (alpha-1-antitrypsin*) of Fig. 7; E, native alpha-1antitrypsin*; and F, native elastase. The arabic numbers to the right represent the mobilities of the complex (band 1), alpha-1antitrypsin (band 2), alpha-1-antitrypsin* (band 3); and elastase (band 4). All samples contained $35 \mu \mathrm{g}$ of protein except for the complex, gel A, which had $20 \mu \mathrm{g}$, and elastase, gel F, which had $15 \mu \mathrm{g}$. Anode at bottom.

column $(1.5 \times 30 \mathrm{~cm})$, containing DE-52 equilibrated with the same buffer, and elution was effected with a linear gradient from 0.025 to $0.125 \mathrm{M}$ sodium chloride (Fig. 7). 


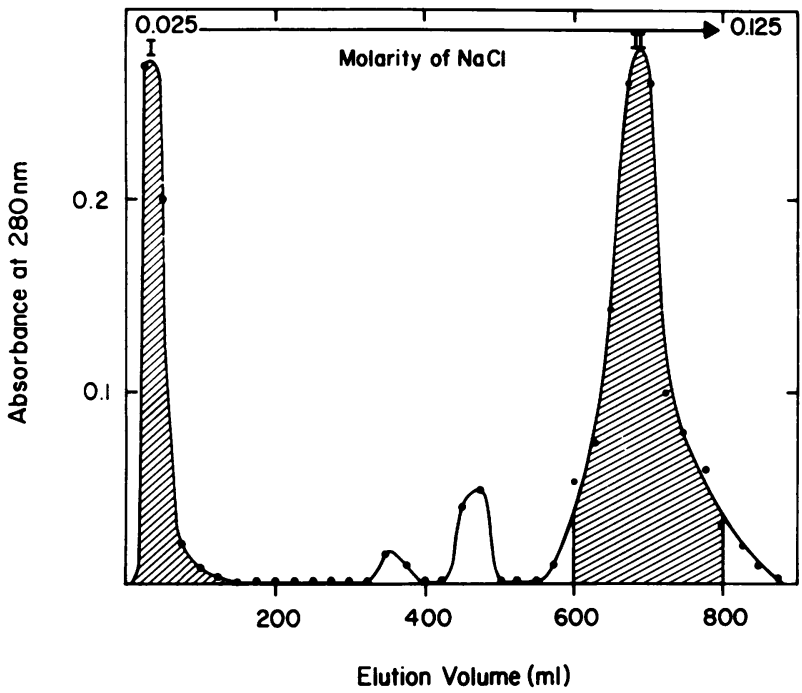

FIGURE 7 Elution profile for purification of alpha-1-antitrypsin* on DE-52 cellulose. Fractions indicated by diagonal lines were pooled for recovery of peak I (elastase) and peak II (alpha-1-antitrypsin*) material as indicated. See the text for description of this column.

Peak I contained free elastase, as determined by observed immunoprecipitation against antiserum to elastase, failure of formation of an immunoprecipitate with antiserum to alpha-1-antitrypsin and by the electropherogram shown in Fig. 6, gel C. This elastase had no catalytic activity against the substrate Ac-triAlaMe, had amino-terminal val and an Mr of 26,400 (Table I). Peak II contained alpha-1-antitrypsin*, as determined by immunoprecipitation against antiserum to alpha-1antitrypsin, by failure of formation of an immunoprecipitate with antiserum to elastase and by the electropherogram shown in Fig. 6, gel D. Alpha-1-antitrypsin* did not inhibit trypsin or elastase, had amino-terminal ser and asx residues by dansyl chloride analysis, and had an Mr of 50,100 (Table I). The sequence of the first six amino acids was ser-ile-pro-pro-glx-val. ${ }^{2}$ The asx detected by the dansyl chloride method was apparently below the limit of detection of the sequencer, and therefore must have arisen from a very minor additional cleavage near the amino-terminal side of alpha-1-antitrypsin*.

During the exposure of the complex to alkaline conditions, a finely dispersed precipitate formed. The precipitate did not redissolve on return of the $\mathrm{pH}$ to 7.6. When thoroughly washed with water, and dissolved in an aqueous solution of SDS, it was found to exhibit a single band with the same mobility as elastase on SDS-PAG and had amino-terminal val (Table I). The observed precipitation explains the weak appearance

\footnotetext{
${ }^{2}$ Sequence analysis performed by Dr. S. K. Chan, University of Kentucky, Lexington, Ky.
}

of the elastase band in the cleaved complex pattern shown in Fig. 6, gel B. Porcine elastase, which has an approximate $\mathrm{pK}_{\mathrm{a}}(6)$ of inactivation of 11.4 , is known to be unstable under alkaline conditions (40).

Carboxy-terminal analysis of alpha-1-antitrypsin, inactive alpha-1-antitrypsin, and alpha-1-antitrypsin* It was considered important to the present studies to redetermine the carboxy-terminal residue of the inhibitor preparation being used, particularly as there are conflicting reports in the literature as to the carboxyterminal residue of human alpha-1-antitrypsin (5, 41-44). Thus, alpha-1-antitrypsin (20-nmol quantities) was reacted with carboxypeptidase $Y$ at an enzyme:substrate ratio of $1: 100$ (weight/weight) for periods of 20,60 , and $120 \mathrm{~min}$. The following amounts ( $\mathrm{nmol}$ ) of lys were released: 4.8 (20 $\mathrm{min})$; 9.0 (60 $\mathrm{min})$; and 16.6 (120 $\mathrm{min})$. Thus it was concluded that lys was the carboxyterminal residue of the alpha-1-antitrypsin preparation used in these studies (Table I). That either lys $(41,42)$ or leu $(5,43,44)$ has been identified as the carboxyterminal residue of native alpha-1-antitrypsin in previous reports could be related to minor differences in the molecule which have to do with minor phenotype MM variations (19) or to post-translational proteolytic modification of the inhibitor.

Purified inactive alpha-1-antitrypsin and alpha-1antitrypsin*, $10 \mathrm{nmol}$, were subjected to carboxy-terminal analysis with carboxypeptidase $Y$. The enzyme: substrate ratio for both analyses was 1:20 (weight/ weight), and the reaction time was $24 \mathrm{~h}$. The major residues and their amounts (residues/mol of substrate) released from inactive alpha-1-antitrypsin were leu (1.09) and thr (0.71), and those released from alpha-1antitrypsin* were leu (0.53) and thr (0.32). Inactive alpha-1-antitrypsin was apparently a better substrate for carboxypeptidase $\mathrm{Y}$ than was alpha-1-antitrypsin* as only about one-half of the corresponding residues were released from the latter. Use of more standard conditions with this carboxypeptidase (e.g., lower enzyme:substrate ratios and shorter reaction times, as for native alpha-1-antitrypsin) did not release sufficient amounts of residues from either of these two modified forms of the inhibitor to be accurately quantified. Likewise, use of other carboxypeptidases, as in previous studies in this laboratory $(5,45)$, was also unsuccessful. It was thus concluded that the dipeptide thr-leu is carboxy-terminal on both of these modified forms of the inhibitor (Table I).

\section{DISCUSSION}

Lower molecular weight alpha-1-antitrypsin-elastase complexes than that described in these studies have been reported previously $(11,12)$. These complexes were seen with higher molar ratios of enzyme to inhibitor, and they may be formed by degradation of the higher molecular weight complexes by elastase mole- 
cules which were transiently diverted to the cleavage site which results in inactive alpha-1-antitrypsin. In addition, because a part of the alpha-1-antitrypsin is inactivated by elastase, higher molar ratios of inhibitor to elastase than the ratio necessary to inhibit trypsin, as seen from the data illustrated in Fig. 1, are necessary to prevent the occurrence of free active elastase and the degradation of the high molecular weight complexes. No complex has been observed with a higher mass ratio than the sum of the molecular weights of the two reactants, which indicates that alpha-1-antitrypsin does not form a complex that contains more than one elastase molecule.

The data presented show that when alpha-1-antitrypsin is combined with elastase with a large excess of inhibitor, more than one reaction takes place (Fig. 8). The elastase hydrolyzes the alpha-1-antitrypsin at a leu-y peptide bond near the carboxy-terminal end of the inhibitor, which results in a molecule with an $\mathrm{Mr}$ of $\cong 51,300$ (inactive alpha-1-antitrypsin) which has an unchanged amino-terminus, and which is no longer capable of inhibiting enzymes. However, it is proposed (Fig. 8) that if alpha-1-antitrypsin is first cleaved at an $x$-ser peptide bond, apparently near the amino-terminal end, before the inactivating cleavage which occurs near the carboxy-terminal end, then the alpha-1-antitrypsin molecule can form a stable complex with elastase. At high molar excess of inhibitor, all of the inhibitor in the complex has sustained the amino-terminal cleavage and none of the inactive alpha-1-antitrypsin has undergone this cleavage. This distribution of peptide cleavages suggests the following hypothesis. The close proximity of the elastase molecule which causes the initial cleavage of alpha-1-antitrypsin at the $x$-ser pep-
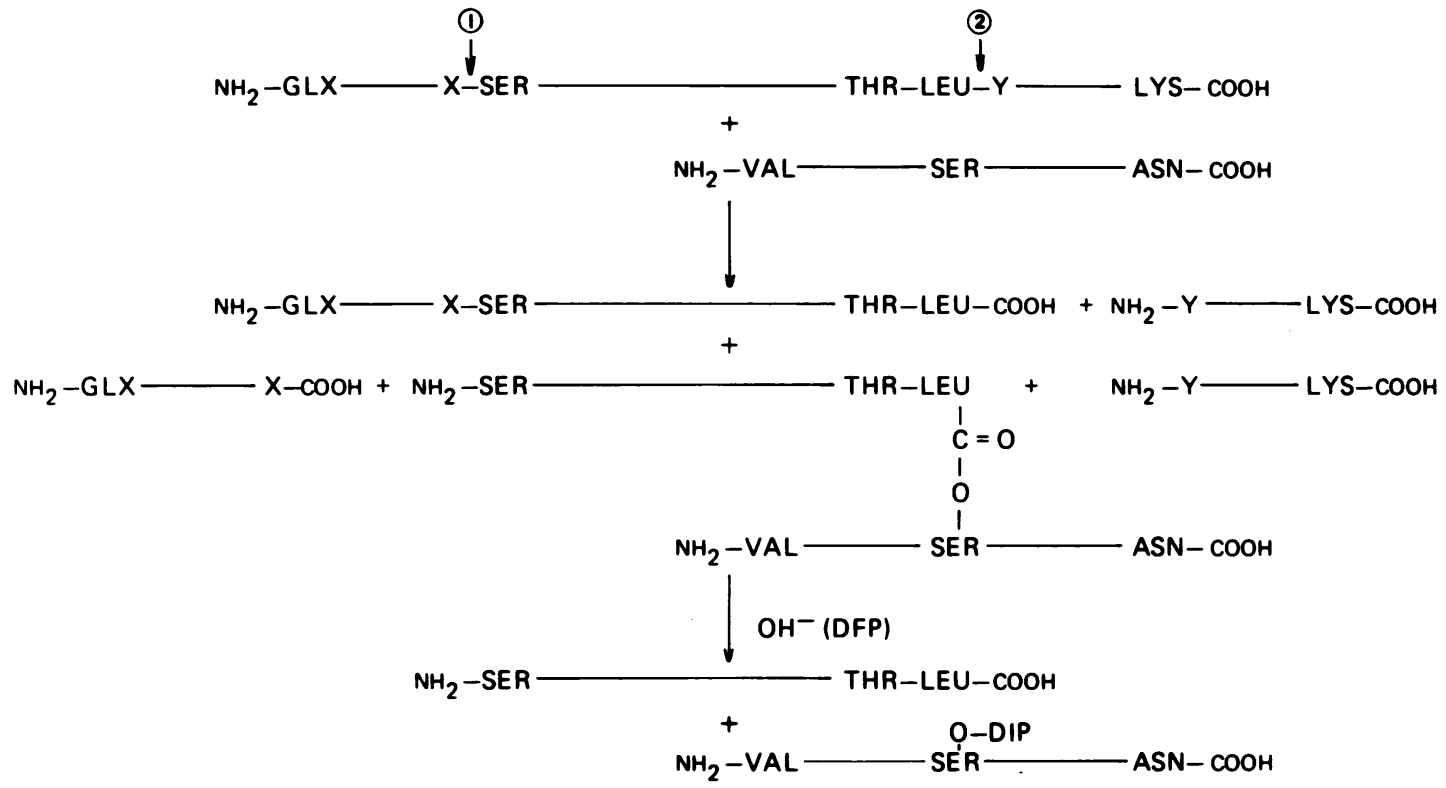

FIGURE 8 Schematic representation of the proposed mechanism of interaction of human alpha-1antitrypsin with porcine pancreatic elastase. The lengths of the horizontal lines are not intended to represent polypeptide chain length. Abbreviations apart from those used for amino acid moieties are: $\mathrm{X}$ and $\mathrm{Y}$, unidentified amino acid moieties at the two peptide bonds (indicated by encircled numbers 1 and 2) in alpha-1-antitrypsin attacked by elastase; $\mathrm{NH}_{2}$ and $\mathrm{COOH}$, aminoterminal and carboxy-terminal ends of the indicated intact proteins, or fragments thereof; $\mathrm{OH}^{-}$, sodium hydroxide used to cleave the complex; and DIP, diisopropyl phosphoryl moiety. The portions of the scheme designated by capital letters are as follows: A, native alpha-1-antitrypsin; $B$, native elastase; $C$, inactive alpha-1-antitrypsin and carboxy-terminal peptide; $D$, amino-terminal peptide, alpha-1-antitrypsin-elastase complex, and carboxy-terminal peptide; E, alpha-1antitrypsin*; and F, the diisopropyl phosphoryl derivative of elastase. If the peptide bond at (2) is attacked first, then inactive alpha-1-antitrypsin is formed. However, if the bond at (1) is first attacked, subsequent reaction of the enzyme at (2) results in the formation of a stable acyl ester bond between the active-site ser moiety of the enzyme and the depicted leu moiety of the inhibitor, this being the basis of complex formation. Under alkaline conditions in the presence of DFP, the complex is hydrolyzed to free alpha-1-antitrypsin* and diisopropyl phosphoryl-elastase. The amino-terminal peptide, $\mathrm{NH}_{2}-\mathrm{GLX}-\mathrm{X}-\mathrm{COOH}$, and the carboxy-terminal peptide, $\mathrm{NH}_{2}-\mathrm{Y}$-LYS-COOH, have a calculated $\mathrm{Mr}$ of 1,200 and 2,700, respectively, on the basis of the data given in Table I. 
tide linkage forces the same enzyme molecule to become complexed with the molecule of alpha-1-antitrypsin thus cleaved. A stable bond then forms at the same leu-y peptide linkage which would otherwise have been cleaved to produce free, inactive alpha-1-antitrypsin.

The alpha-1-antitrypsin-trypsin complex is also alkaline labile. We have demonstrated that, when the hydrolysis of the complex is catalyzed by ${ }^{18} \mathrm{OH}^{-}$, the new carboxy-terminal lysine residue becomes labeled with ${ }^{18} \mathrm{O}$ (45). These studies conform to the known distribution of oxygens which occurs during the base-catalyzed hydrolysis of acyl esters (46-48) and which would be likely to occur if the complex were an acyl ester or if an acyl intermediate formed during the base-catalyzed hydrolysis of a tetrahedral adduct. The alkaline lability of the alpha-1-antitrypsin-elastase complex makes a similar mechanism likely.

In conclusion, there may be only two major sites in alpha-1-antitrypsin which are attacked by elastase. If the site near the carboxy-terminal end is attacked first, the bond is cleaved. However, if the amino-terminal cleavage occurs first, then the inhibitor molecule undergoes a change which causes the elastase enzyme molecule to bind tightly in a stable complex at the same site near the carboxy-terminal end which would otherwise have led to a "nonproductive" cleavage and the formation of inactive alpha-1-antitrypsin. While this hypothesis is a logical interpretation of the present observations, the observed covalent changes in the inhibitor molecule do not necessarily prove that the initial removal of the amino-terminal peptide is an activation process. Further studies are under way in this laboratory to isolate and characterize the peptides released from alpha-1-antitrypsin, as postulated in Fig. 8. This approach, and the prospect of labeling the apparent active-site leu residue in the inhibitor with ${ }^{18} \mathrm{OH}^{-}$as in the previous studies on alpha-1-antitrypsin-trypsin complex formation (45), would be of benefit in further establishing the molecular events in the inhibition of serine proteases by alpha-1-antitrypsin.

\section{ACKNOWLEDGMENTS}

The authors acknowledge the skilled technical assistance of Ms. Eileen Silver and Ms. Dagmar Geczy throughout the course of these studies. We are indebted to Dr. Kenneth Hoober and Mrs. Ruth Millington, Department of Biochemistry, for many helpful discussions and amino acid analyses on the Beckman model 119 analyzer, and to Dr. Friedrich Kueppers and Mrs. Barbara Harpel, Department of Medicine, for analysis of alpha-1-antitrypsin phenotypes by gel isoelectric focusing.

This work was supported in part by U. S. Public Health Service, National Heart, Lung, and Blood Institute grants: Pulmonary Program Project grant 1 PO 1 HL 20994-01, RCDA 1 KO 4 HL 00153-03, 1 RO 1 HL 18543-03, and by the Council for Tobacco Research, U. S. A., grant 954B.

\section{REFERENCES}

1. Laurell, C-B., and S. Ériksson. 1963. The electrophoretic $\alpha_{1}$-globulin pattern of serum in $\alpha_{1}$-antitrypsin deficiency. Scand. J. Clin. Lab. Invest. 15: 132-140.

2. Heimburger, N., H. Haupt, and H. G. Schwick. 1971. Proteinase inhibitors in human plasma. In Proceedings of the International Research Conference on Proteinase Inhibitors. H. Fritz and H. Tschesche, editors. Walter de Gruyter Inc., Elmsford, New York. 1-21.

3. Cohen, A. B. 1976. $\alpha_{1}$-Antitrypsin as a systemic determinant of lung structure and function. In The Biochemical Basis of Pulmonary Function. R. Crystal, editor. Marcel Dekker, Inc., New York. 313-360.

4. Naughton, M. A., and F. Sanger. 1961. Purification and specificity of pancreatic elastase. Biochem.J. 78: 156-163.

5. Cohen, A. B., D. Geczy, and H. L. James. 1978. The interaction of human $\alpha$-1-antitrypsin with porcine trypsin. Biochemistry. 17: 392-400.

6. Shotton, D. M. 1970. Elastase. Methods Enzymol. 19: 113140.

7. Janoff, A. 1969. Alanine $p$-nitrophenyl esterase activity of human leukocyte granules. Biochem. J. 114: 157-159.

8. Janoff, A. 1972. Neutrophil proteases in inflammation. Annu. Rev. Med. 23: 117-190.

9. Legrand, Y., J. P. Caen, L. Robert, and J. L. Wautier. 1977. Platelet elastase and leukocyte elastase are two different entities. Thromb. Haemostasis. 37: 580-582.

10. Rodriquez, R. J., R. R. White, R. M. Senior, and E. A. Levine. 1977. Elastase release from human alveolar macrophages: Comparison between smokers and nonsmokers. Science (Wash. D. C.). 198: 313-314.

11. Lo, T. N., A. B. Cohen, and H. L. James. 1976. The interaction of $\alpha$-1-antitrypsin with soluble and Sepharosebound elastase. Biochim. Biophys. Acta. 453: 344-356.

12. Baumstark, J. S., C. T. Lee, and R. J. Luby. 1976. Rapid inactivation of $\alpha_{1}$-protease inhibitor ( $\alpha_{1}$-antitrypsin) by elastase. Biochim. Biophys. Acta. 482: 400-411.

13. James, H. L., and A. B. Cohen. 1978. Analysis of a complex of human $\alpha_{1}$-antitrypsin (AAT) and porcine pancreatic elastase. Fed. Proc. 37: 1336. (Abstr.)

14. Crawford, I. P. 1973. Purification and properties of normal human $\alpha_{1}$-antitrypsin. Arch. Biochem. Biophys. 156: 215222.

15. Pannell, R., D. Johnson, and J. Travis. 1974. Isolation and properties of human plasma $\alpha$-1-proteinase inhibitor. Biochemistry. 13: 5439-5445.

16. Laurell, C-B., J. Pierce, U. Persson, and E. Thulin. 1975. Purification of $\alpha_{1}$-antitrypsin from plasma through thioldisulfide interchange. Eur. J. Biochem. 57: 107-113.

17. Travis, J., J. Bowen, D. Tewksbury, D. Johnson, and R. Pannell. 1976: Isolation of albumin from whole plasma and fractionation of albumin depleted plasma. Biochem.J. 157: $301-306$.

18. Cohen, A. B., and H. L. James. 1978. Evaluation of alpha1-antitrypsin as a potential therapeutic agent. In Proceedings of the International Workshop on Technology for Protein Separation and Improvement of Blood Plasma Fractionation. H. E. Sandberg, editor. Department of Health, Education and Welfare pablication. 78-1422: 326-338.

19. Kueppers, F. 1976. Determination of $\alpha_{1}$-antitrypsin phenotypes by isoelectric focusing in polyacrylamide gels. $J$. Lab. Clin. Med. 88: 151-155.

20. Walsh, K. A., and P. E. Wilcox. 1970. Serine proteases. Methods Enzymol. 19: 31-41. 
21. Chase, T., Jr., and E. Shaw. 1970. Titration of trypsin, plasmin and thrombin with $p$-nitrophenyl $\dot{p}$-guanidinobenzoate HCL. Methods Enzymol. 19: 20-27.

22. Buck, F. F., A. J. Vithayathil, M. Bier, and F. F. Nord. 1962. On the mechanism of enzyme action. Studies on trypsins from beef, sheep, and porcine pancreas. Arch. Biochem. Biophys. 97: 417-424.

23. Powers, J. C., and D. L. Carroll. 1975. Reaction of acyl carbazates with proteolytic enzymes. Biochem. Biophys. Res. Commun. 67: 639-644.

24. Gertler, A., and T. Hofmann. 1970. Acetyl-L-alanyl-Lalanyl-L-alanine methyl ester: A new highly specific elastase substrate. Can. J. Biochem. 48: 384-386.

25. McFarlane, A. S. 1963. In vivo behavior of $I^{131}$-fibrinogen J. Clin. Invest. 42: 346-361.

26. Gray, W. R. 1972. End-group analysis using dansyl chloride. Methods Enzymol. 25: 121-138.

27. Mosesson, M. W., J. S. Finlayson, and D. K. Galanakis. 1973. The essential covalent structure of human fibrinogen evinced by analysis of derivatives formed during plasmin hydrolysis. J. Biol. Chem. 248: 7913-7929.

28. Woods, K. R., and K. T. Wang. 1967. Separation of dansylamino acids by polyamide layer chromatography. Biochim. Biophys. Acta. 133: 369-370.

29. Hayashi, R., S. Moore, and W. H. Stein. 1973. Carboxypeptidase from yeast. Large scale preparation and the application to COOH-terminal analysis of peptides and proteins. J. Biol. Chem. 248: 2296-2302.

30. Hayashi, R. 1976. Carboxypeptidase Y.Methods Enzymol. 45: 568-587.

31. Spackman, D. H., W. H. Stein, and S. Moore. 1958. Automatic recording apparatus for use in the chromatography of amino acids. Anal. Chem. 30: 1190-1206.

32. Brauer, A. W., M. N. Margolies, and E. Haber. 1975. The application of $0.1 \mathrm{M}$ Quadrol to the microsequence of proteins and the sequence of tryptic peptides. Biochemistry. 14: 3029-3035.

33. Ouchterlony, Ö. 1968. Handbook of Immunodiffusion and Immunoelectrophoresis. Ann Arbor Science Publishers, Inc., Ann Arbor, Mich.

34. Mancini, G., A. O. Carbonara, and J. F. Heremans. 1965. Immunochemical quantitation of antigens by single radial immunodiffusion. Immunochemistry. 2: 235-254.

35. Davis, B. J. 1964. Disc Electrophoresis-II. Method and application to human serum proteins. Ann. N. Y. Acad. Sci. 121: 404-427.
36. Weber, K., and M. Osborn. 1969. The reliability of molecular weight determinations by dodecyl sulfate-polyacrylamide gel electrophoresis.J. Biol. Chem. 244: 4406-4412.

37. Laemmli, U. K. 1970. Cleavage of structural proteins during the assembly of the head of bacteriophage T4. Nature (Lond.). 227: 680-685.

38. Hokin, L. E., J. L. Dahl, J. D. Dupree, J. F. DIxon, J. F. Hackney, and J. F. Perdue. 1973. Studies on the characterization of the sodium-potassium transport adenosine triphosphatase. X. Purification of the enzyme from the rectal gland of Squalus acanthias. J. Biol. Chem. 248: 2593-2605.

39. Schultze, H. E., and J. F. Heremans. 1966. Molecular Biology of Human Proteins. Elsevier North-Holland, Inc., New York. 1: 190.

40. Geneste, P., and M. L. Bender. 1969. Esterolytic activity of elastase. Proc. Natl. Acad. Sci. U. S. A. 64: 683-685.

41. Johnson, D. A., and J. Travis. 1976. Human alpha-1-proteinase inhibitor mechanism of action: evidence for activation by limited proteolysis. Biochem. Biophys. Res. Commun. 72: 33-39.

42. Plancot, M-T., A. Delacourte, K-K. Han, M. Dautrevaux, and G. Biserte. 1977. Isolation and characterization of highly purified alpha-l-anti-trypsin. Int. J. Pept. Protein Res. 10: 113-119.

43. Horng, W. J., and J. C. Gan. 1974. Purification and characterization of human plasma $\alpha_{1}$-antitrypsin. Tex. Rep. Biol. Med. 32: 489-504.

44. Chan, S. K., D. C. Rees, S-C. Li, and Y-T. Li. 1976. Linear structure of the oligosaccharide chains in $\alpha_{1}$-protease inhibitor isolated from human plasma. J. Biol. Chem. 251: 471-476.

45. Cohen, A. B., L. D. Gruenke, J. C. Craig, and D. Geczy. 1977. Specific lysine labeling by ${ }^{18} \mathrm{OH}^{-}$during alkaline cleavage of the $\alpha$-1-antitrypsin-trypsin complex. Proc. Natl. Acad. Sci. U. S. A. 74: 4311-4314.

46. Polyani, M., and A. Szabo. 1934. Mechanism of hydrolysis. Alkaline saponfication of amyl acetate. Trans. Faraday Soc. 30: 508-512.

47. Bender, M. L. 1951. Oxygen exchange as evidence for the existence of and intermediate in ester hydrolysis. J. Am. Chem. Soc. 73: 1626-1629.

48. Bender, M. L., and R. J. Thomas. 1961. The concurrent alkaline hydrolysis and isotopic oxygen exchange of a series of $p$-substituted methyl benzoates. J. Am. Chem. Soc. 83: 4189-4196. 